The successor to the journal Music Review, Nineteenth-Century Music Review aims to locate music within the widest possible framework of intellectual activity pertaining to the long nineteenth century (c.1789-1914). It particularly welcomes interdisciplinary scholarship that explores music within the context of other artistic and scientific discourses. Articles with fine visual or iconographic content are encouraged, as are those rich in musically illustrative material. Articles accepted for publication will reflect a diversity of critical viewpoints.

\title{
Contents of Volume 4, Issue 2
}

Articles

Susan Wollenberg

Marcia J. Citron

Nancy B. Reich

Harald Krebs

Briony Williams

Matthew Head

R. Larry Todd

Susan Wollenberg

Beatrix Borchard and Cornelia Bartsch

Review Article Jonathan Kregor
Introduction

A Bicentennial Reflection: Twenty-five Years with Fanny Hensel

The Diaries of Fanny Hensel and Clara Schumann: A Study in Contrasts

The 'Power of Class' in a New Perspective: A Comparison of the Compositional Careers of Fanny Hensel and Josephine Lang

Biography and Symbol: Uncovering the Structure of a Creative Life in Fanny Hensel's Lieder

Genre, Romanticism and Female Authorship: Fanny Hensel's 'Scottish' Sonata in G Minor (1843)

Fanny Hensel's Op. 6, No. 1 and the Art of Musical Reminiscence

Fanny Hensel's Op. 8, No. 1: A Special Case of 'multum in parvo'?

Leipziger Straße Drei: Sites for Music

Liszt, Yesterday and Today: Franz Liszt and His World

Book Reviews

CD Reviews

Score Reviews

Published in association with the Centre for Nineteenth-Century Music, Durham University, UK

Cover illustration: Programme of Clara Schumann's concert in Göttingen, 29 October 1855

\section{ASHGATE}

Ashgate Publishing Limited Gower House, Croft Road Aldershot, Hampshire GU11 3HR, England www.ashgate.com

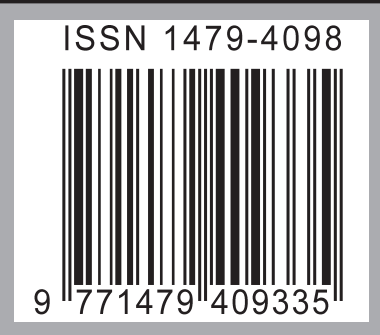

